\title{
Scanning ultrastructural ontogeny of cleistothecia in the powdery mildew Microsphaera alphitoides
}

\author{
KATARZYNA TURNAU, MAGDALENA CZERWONKA
}

T u r n a u K. (Department of Taxonomy and Phytogeography, Institute of Botany of the Jagiellonian University, Lubicz 46, 31-512 Kraków, Poland) C z e r'w o n k a M. (Department of Comparative Anatomy, Institute of Zoology of the Jagiellonian University, Karasia 6 $30-060 \mathrm{~K}$ raków, Poland). Scanning ultrastructural ontogeny of cleistothecia in powdery mildew Microsphaera alphitoides, Acta Mycol. 22(2): 223-226, 1986 (1988).

Morphogenesis of cleistothecia in Microsphaera alphitoides Griff. et Maubl. (Erysiphales, Ascomycetes) on naturally infected leaf of oak was investigated with the scanning electron microscope. All phases of the life cycle of this species have been described. Some comparisons between methods of preparation of the material have been made.

\section{INTRODUCTION}

Microsphaera alphitoides Griff. et Maubl. is a very frequent species which causes the plant disease commonly referred to as powdery mildew. Only a few kinds of powdery mildew have been studied with SEM. Genus Microsphaera appeared only in papers by $\mathrm{Yuk}$ a w a, K a t a mot o, Tok a h a s h i (1971) and by $\mathrm{H}$ a $\mathrm{r} \mathrm{r}$ is, $\mathrm{R}$ ot h (1974). The first deals with $M$. euonymi-japonicus and the second - with Microsphaera sp. collected from Quercus stellata leaves on dried unifixed material. The present study therefore was undertaken to obtain data on the phases of cleistothecial morphogenesis and were provided on fresh fixed material.

\section{MATERIALS AND METHODS}

Naturally infected by Microsphaera alphitoides leaves of Quercus robur were collected from the Ojców National Park (South of Poland, Cracow-Wieluń Upland) in 1984. They were fixed for 30 minutes in $3 \%$ glutaraldehyde in $0,2 \mathrm{M}$ phosphate buffer, $\mathrm{pH}$ 7.2. The fixed material was rinsed several times in the same buffer and dehydrated in a 30 to $100 \%$ ethanol series (10 at each step). The 
samples were at the critical point dried with $\mathrm{CO}_{2}$, coated with carbon and gold, and observed with a JSM-35 scanning electron microscope (SEM) at $25 \mathrm{kV}$. A few naturally dried pieces of infected leaves were not fixed in the above described way, but only coated with carbon and gold and also examined with SEM.

\section{RESULTS}

All stages of Microsphaera alphitoides life cycle have been found on naturally infected oak leaves from Ojców. Powdery mildew colonies were macroscopic and appeared as powdery white mass on the leaf surface. Both the upper and lower epidermis has been infected by hyphae ca. $2-3 \mu \mathrm{m}$ thick. Hyphae, growing on the surface of leaves, develop attachments to the cuticle, called appressoria (Pl. I. A.) and penetrate host tissue by haustoria - the feeding organ. The asexual reproductive cycle was completed by the production of ellipsoidal conidiospores. This state, called Oidium quercinum Thüm, has been described by several authors (C e j p, S k a 1 i c k ý 1954; B 1 u m e r 1967 and others). Cleistothecia were initiated by plasmogamy of a single mycelial bulbous like cell ca. 3-4 $\mu \mathrm{m}$ in diameter (Pl. I. B) and a spherical cell ca. 1.2-2 $\mu \mathrm{m}$ in diameter functioning as antheridia (Pl. I. C, D). As ascogonium develops, it undergoes further division, forming ascogonial hyphae (PI. II. $A, B$ ). In further development hyphae near the ascogonium produce branches (Pl. II. $C$, III. $A$ ) which begin to form the cover of ascogonial hyphae. They become more septate and swollen than those from which they have arisen. The fruit-bodies at this phase are ca. $30-40 \mu \mathrm{m}$ in diameter. On the lower surfaces of the ascocarp they form attachments to the surface of leaf from vegetative hyphae. In Pl. III. A we can find a hyphe growing and branching on the surface of ascocarp. Such hyphae probably make a net of ridges visible at the end of ontogeny. But as they appear the ascocarp becames covered by interstitial mucilage visible on the surface of the fruit-body which appears in SEM as a membranous material. As the growing appendages arised there are remnants of this mucilage at the top of them (PI. IV. A). Pl. IV-VI show completely developed fruit-bodies. Appendages are directed at the begining down to the surface of the leaf and their ends are entangled into a net or vegetative hyphae (Pl. IV. B). Later the appendages are changing their position upwards ( $\mathrm{Pl}$. IV. C). Pl. IV. $D$ shows different positions of appendages. As cleistothecium matures it becames marked by ridges (Pl. V. A). In fixed material ( $\mathrm{Pl} . \mathrm{V}, B)$ appendages ornamentation is hardly visible but if unfixed specimens are considered it becomes more distinct (Pl. V. C, D). In dried material endings of appendages in particular collapse (Pl. V. D).

\section{DISCUSSION}

In this investigation ontogeny of cleistothecia in Microsphaera alphitoides was followed in the SEM. It may help in considering similarities and diferences 
Plate I

$A$ - appresoria $(\times 3000) ; B$ - ascogonium attached to the hyphac $(\times 3000) ; C$ - fusion of ascogonium and antherydium $(\times 5000): D-$ male cells produced by hyphac $(\times 2500)$
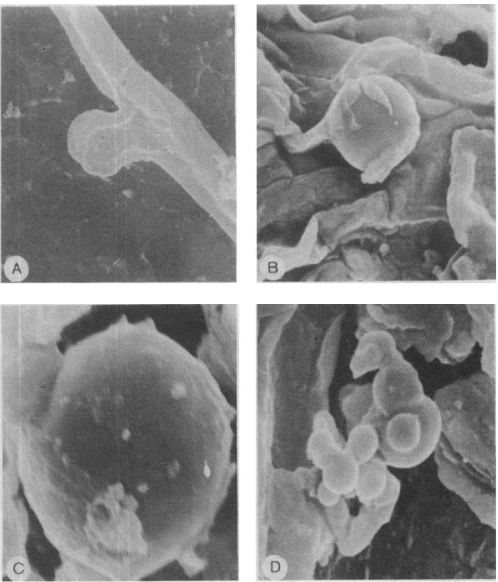


\section{Plate II}

$A, B$ - ascogonial hyphae begining to arise from ascogonium $(A-\times 5000, B-\times 3900)$, $C-$ hyphae from nearly vegetative cells growing toward and around ascogonium $\times 1200$ )
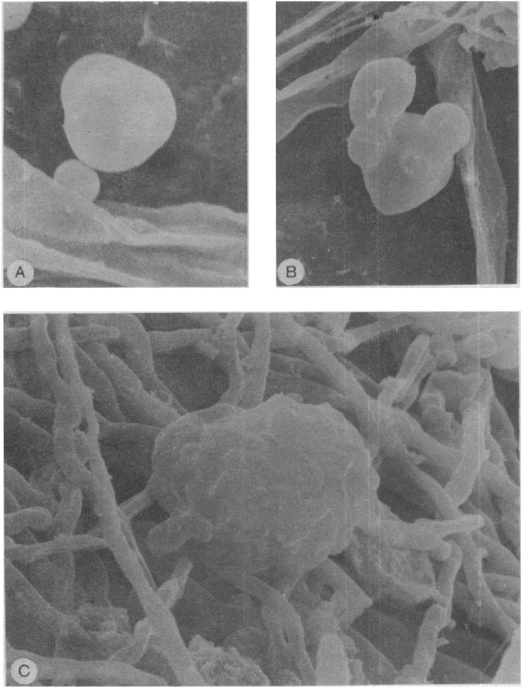


\section{Plate III}

A - the beginning of production of external seath by hyphac branching on the surface of the ascocarp. Note a few hyphae attaching ascocarp to the surface of leaf (x 500$), B$ - upper surface of oak leaf with a various stages of $M$. alphitoides $(\times 200)$
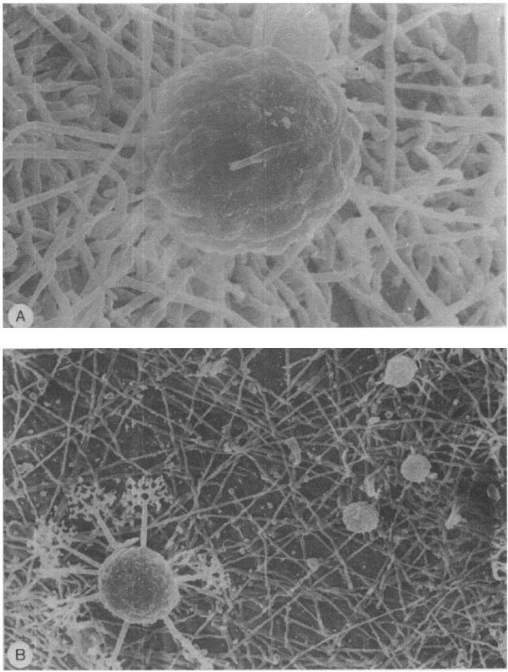
Plate IV

$A$ - the begining of formation of appendages. Note membranous material on ascocarp and the top of appendages $(\times 600 ; B$ - mature fruit-body with appendagesentangled into a net of vegetative hyphae ( $\times 500$ ), $C$ - mature ascocarp with appendages upwards ( $\times 330$; $D$ - a few mature ascocarps in a various stage of position of appendages $(\times 170)$
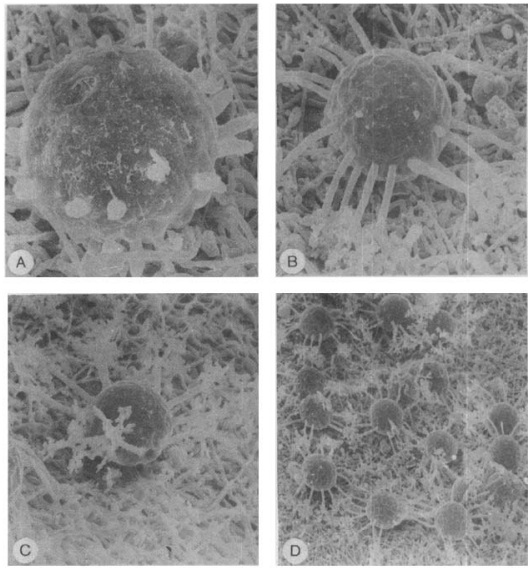


\section{Plate V}

A - the mature ascocarp surface with ridges ( $\times 3000$; $B$ - dichotomously branched ends of appendages in fixed material ( $x 900)$, $C$ - the basal part of appendage after drying of material $(x$ 6000 : $D$ - the end of appendage after drying of material. Note the collaption of hyphae ( $x \quad 1600$ )
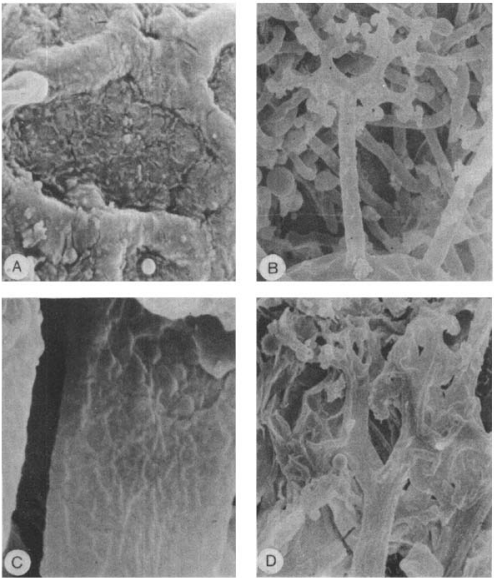
between this and related species. For example, the identity of $M$. alphitoides and M. hypophylla Nevod. has not been decided up till now (S a t a t a 1985; $\mathrm{S}$ p e e r 1973). As we know from other papers and from our investigation $M$. alphitoides posessed less and shorter appendages then in M. hypophylla. Their hook like ends are also very characteristic.

As we know from previous papers (cited by $\mathrm{S}$ a $\mathrm{f}$ a $\mathrm{t}$ a 1985) these species like Erysiphe sordida, Phyllactinia guttata, Sphaerotheca mors-uvae and others are belived to be apomictic because of degeneration of the antheridial nucleus. In our study we only observed the external process of fusion of ascogonium and minute antheridium which is not easily visible using the light microscope.

This investigation carried out on fixed fresh as well as on naturally dried material has revealed the volume of the scanning electron microscope in the following developmental events in fungi. Working on dried material we found possibilities of deformations of hyphae, appendages and others.

We express out thanks to Professor Dr. Wincenty Kilarski - Director of Comparative Anatomy Department. Institute of Zoology of the Jagiellonian University, Krakow, who kindly made our investigation with scanning elect ron microscope possible.

\title{
REFERENCES
}

B I u m e r S. 1967. Echte Mehltaupilec (Erysiphaceae) - Ein Bestimmung buch für die in Europa verkommenden Arten. Jena.

C ejp K.. Skalick y V. 1954, Plodna padi na dubech v Ceskoslovensku, Microsphaera alphitoides Griffon et Maublanc a Phyllactinia raboris (Gachet) Blumer, Preslia 26: 43-54.

$\mathrm{H}$ a r $\mathrm{r}$ is J. L., R o t h 1. L. 1975, Scanning electron microscopy of perithecial development in a species of Microsphatra on oak. Can. 1. Bo4. 53; 279-283.

Sat at a B. 1985, Workowo (Ascomycetes) Maczniakowoe (Erysiphaks) (in:) Grzyby (M/cora) Flora Polska - Rosliny zarodnik owe Polski i Ziem Osciennych. XV, Kraków-Warszawa.

S p e e r E. O.. 1973. Untersuchungen zur Morphologe und Systematik der Erysiphaceen. II. Der Eichenmehlıu. Micresphaera alphitodies Griff. et Maubl. Ibidem 27: 112-126.

Yuk a w a Y. K a t a m o to K. T a k a h a s h i H. 1971.Studies on Microsphaeraeucnymifaponicae Vienn, - Bourg, and its hyperparasity. I. Scanning electron microscopic observations on the mycoparasitism, Bull. Fac. Agric. Yamaguti. Univ. 22: 197-208.

\section{Ontogeneza kleistotecjów Microsphaera alphitoides Griff. et Maubl. obserwowana $w$ mikroskopie skanningowym}

\author{
Streszezenic
}

W pracy opisan o kolejne elapy cyk lu 2yciowego Microsphaera aiphiioides (mąkulka dębowa). poopoli icgo pasoźy ta dębów. Infekcja rozpočyna siç od porosiniçcia liści grzy bnia przycrepiająca siç do powierzehni skórki za pomocu przylg oraz wytwarzająci haust oria wrastajł̨e do wnętrza tkanek. 
Rozmnazanie rozpoczyna się fuzją anterydium i askogonium, rózniących sį̨ $\propto$ siebie rozmiarami. Z askogonium wyrastaja strzepki ask ogenicne, podczas gd y słsiadujace $z$ nim strzępki wegetaty wne tworza okrywę (ścianę owocrika). Dojrzaly owocnik osiaga średnicę ok olo $100 \mu \mathrm{m}$ i opatrzony jest charakterystycznymi, wielok rotnie dychotomicznie rozgalezionymi przyczepk ami o hak owatych zakonczeniach. Praca ilustrowana jest kilkunastoma zdjęciami $z$ mikroskopu skaningowego wykonanymi $z$ preparató w uzyskanych $z$ materialu utrwalonego jak i wysuszonego. 